\title{
CROSS-CULTURAL MANAGEMENT IN CHINA: COMPETENCIES OF CHINESE BUSINESS STUDENTS
}

\author{
Tobias Cramer \\ University of Economics, Prague, Czech Republic
}

\begin{abstract}
The ability to deal with cross-cultural differences has grown in importance due to the increasing number of Sino-foreign cooperation and the fact that more and more Chinese companies are investing abroad. The present study examines the cultural awareness and cognitive cultural intelligence (cognitive CQ) of Chinese undergraduate students. The results show that Chinese undergraduate business students are moderately culturally aware and display average cognitive CQ.
\end{abstract}

Keywords: Cross-cultural management, China, Cultural awareness, Cognitive cultural intelligence.

DOI: http://dx.doi.org/10.15549/jeecar.v5i2.220

\section{INTRODUCTION}

The increasing diversification of sales, procurement, and labor markets, as well as a continuously diversifying staff structure, create an external and internal diversity for global companies, to which they have to respond adequately. While globalization is one of the most significant trends in the 21st Century, numerous examples of failed international mergers and acquisitions (M\&As) show that difficulties can occur when individuals from different cultures work together (Maugain, 2003). Technical, financial and strategic issues account for only 30 percent of unsuccessful international corporate collaborations, yet in 70 percent of cases, cross-cultural problems are critical (Fuchs \& Apfelthaler, 2002). Misunderstandings often happen between partners due to a lack of culture awareness (Inkpen \& Currall, 1998). By the end of 2008, $70 \%$ of M\&As by Chinese enterprises had failed (People's Daily Online, 2009), whereas the volume of such M\&As increased considerably, reaching a peak in 2016 (end of August), with
173 deals worth $\$ 128.7$ billion in the US, and 101 transactions worth $\$ 76.5$ billion, in Europe (Mergermarket Group, 2016). Whereas managerial and cultural differences between Chinese and Western corporations do not seem to play a significant role for Chinese investors, a study by the Boston Consulting Group found that they "face major cultural barriers when it comes to integrating a non-Chinese acquisition" and they "lack a deep understanding of customers, competitors, distribution structures, and the regulatory environment in their target markets" (Hemerling et al., 2006, p.16-17). Managers' ability to cope with cultural differences is seen as an example of a company's sustainable competitive advantage (Oliver, 1997).

With an increasing number of Chinese companies investing abroad, and the continuous FDI inflow to China, the need for cross-cultural competences becomes an issue that has to be approached by these enterprises, as well as business schools offering relevant courses for future managers. This study aims to contribute 
to the debate on the degree of cultural awareness and cognitive CQ among Chinese undergraduate business students. The paper is organized as follows: In the next section the conceptual background is discussed. The results of the study are then presented and finally discussed.

\section{BACKGROUND}

\section{Culture}

For this paper, culture is understood as "the collective programming of the mind, which distinguishes the members of one group or category of people from another," (Hofstede, 1991, p.5). Much of the theoretical discussions and empirical research in cultural studies take national culture as the basis. National culture has been shown to impact on major business activities (Leung et al., 2005). To classify nationality is a useful criterion (Hofstede, 2001; Schwartz, 1999), and it is, therefore, also used in this study.

\section{Cultural awareness}

The term cultural awareness is not easily defined either and is often used analogously with concepts such as cultural sensitivity, crosscultural competence, and cross-cultural effectiveness (Ridley et al., 1994). In a broad sense, cross-cultural awareness has been defined as "the understanding and appreciation of different values and behaviors as they are experienced in different cultures and through different languages" (Koyama, 1992, p. 5). Another common understanding of the term is being "generally aware that identity is shaped by cultural influences" (Singelis \& Pedersen, 1997, p. 190). Indeed, the ability to manage cultural differences is seen as an example of a company's sustainable competitive advantage (Oliver, 1997), and cross-cultural awareness has a positive influence on successful cooperation in multinational teams (satisfaction, effectiveness) (Cramer, 2007).

\section{Cultural intelligence}

Cultural intelligence refers to the capability to function effectively in culturally diverse settings (Ang \& Van Dyne, 2008; Earley \& Ang, 2003). This view is based on Sternberg and Detterman
(1986), who developed an integrative framework of intelligences as being multidimensional, i.e. a set of capabilities comprising mental, motivational, and behavioral components, with a specific focus on resolving cross-cultural problems. In this study, cognitive intelligence is of importance. It refers to an individual's knowledge structures, it "reflects knowledge of norms, practices, and conventions in different cultures acquired from education and personal experience" (Ang et al, 2011, p. 584).

\section{Cross-cultural management in China}

Generally, the reference framework of international management does not differ from that of national management; both are assigned as main tasks organization, leadership, management control system, and recruitment (Barsauskas \& Schafir, 2003). Culture as an external dimension is an important factor though, which affects all sub-areas of the company and, therefore, must be taken into account in all company-relevant international decision-making situations. Many Chinese corporations obviously still lack long-term experience in international economic activities, due to China's long period of economic closeness. The Chinese literature on crosscultural Management (CCM) regards China's access to the World Trade Organization in 2001 as a turning point in the importance of CCM for Chinese companies and researchers (Xi, 2004, p.2; in Jungbluth, 2008). Jungbluth (2015) provides an overview of the academic discussion on the topic of CCM in China. As can be seen in table 1 , the acceptance of CCM had started even before.

Empirical studies on CCM in China have been conducted since the 1990s and many important topics and relationships were tested in crosscultural settings. Research shortcomings include insufficient systematic model development and assessment of topics, e.g. teamwork and motivation (Dong \& Liu, 2010). Only a few organizations, doing business internationally, have the competitive advantage of cultural sensitivity, as recruitment and training in CCM is still significantly lacking (ibid.).

Table 1. Academic discussion on the topic CCM in China. 


\begin{tabular}{|c|c|}
\hline Authors & Conclusions \\
\hline $\begin{array}{l}\text { Wei, Zu (1988); Jin, Jun } \\
\text { (1989) }\end{array}$ & - CCM as priority for Western MNEs \\
\hline Hu, Jun (1995) & $\begin{array}{l}\text { - Key to establishing CCM in China lies in a management } \\
\text { theory with Chinese characteristics }\end{array}$ \\
\hline $\begin{array}{l}\text { Zhao, Shuming (1997); } \\
\text { Tang, Jie (1995) }\end{array}$ & $\begin{array}{l}\text { - In e.g. Joint ventures, it is necessary on both sides to } \\
\text { have basic knowledge about the other cultural } \\
\text { background }\end{array}$ \\
\hline Fu, Liyou (1996) & $\begin{array}{l}\text { - CCM is relevant not only to Western MNEs, but to } \\
\text { companies in general } \\
\text { - Foreign investors should not impose their management } \\
\text { style on the Chinese partner, but try to reconcile it with } \\
\text { Chinese practices as far as possible } \\
\text { - Need for CCM also with Chinese companies focusing on } \\
\text { the domestic market in order to overcome regional } \\
\text { differences } \\
\text { - The increasing international expansion of Chinese } \\
\text { companies increases the need for CCM research }\end{array}$ \\
\hline $\begin{array}{l}\text { e.g. Xi, Xudong (2004); } \\
\text { He, Junhong (2002) }\end{array}$ & $\begin{array}{l}\text { - WTO entry as a turning point in the importance of CCM } \\
\text { for Chinese companies and their foreign operations }\end{array}$ \\
\hline Xi, Xudong (2004) & $\begin{array}{l}\text { - The very limited research in China, how to do business } \\
\text { and management in a cross-cultural environment, leads } \\
\text { to substantial restrictions on Chinese transnational } \\
\text { business and trading activities }\end{array}$ \\
\hline e.g. Chen, Xiaoping (2005) & $\begin{array}{l}\text { - Many Chinese publications about CCM are based on } \\
\text { culturally theoretical and culturally comparative } \\
\text { approaches of established Western scientists, primarily } \\
\text { that of Hofstede } \\
\text { - Chinese-language publications are partly translations of } \\
\text { Western publications }\end{array}$ \\
\hline $\begin{array}{l}\text { Li, Yongtai \& Li, Wei } \\
\text { (2003) }\end{array}$ & $\begin{array}{l}\text { - Study "Cultural stages in managing companies" leads to } \\
\text { five indices: Management Orientation, Risking } \\
\text { Orientation, Responsibility Orientation, Thinking Habit, } \\
\text { Accomplishment Orientation (MRRTA model) }\end{array}$ \\
\hline Yang, Xianju (2005) & $\begin{array}{l}\text { - In Master Sun Tsu's treatise "The art of war" is the basis } \\
\text { for a Chinese CCM approach: If you know both yourself } \\
\text { and your enemy, you can win numerous (literally, "a } \\
\text { hundred") battles without jeopardy. }\end{array}$ \\
\hline
\end{tabular}

Source: Jungbluth, 2015, pp. 272-283

\section{Cross-cultural management at Chinese business schools}

The necessity of possessing CCM competencies in the workplace is explicitly required by the Association to Advance Collegiate Schools of Business (AACSB). As part of an accredited business school program, challenges such as "sensitivity toward, and greater understanding of cultural differences and global perspectives" and "students should be exposed to cultural practices different than their own" (AACSB, 2016a, p.6) should be tackled in undergraduate and graduate degree programs.

There are currently 24 Chinese AACSBaccredited universities and schools, 7 of them in Hong Kong (AACSB, 2016b). Not only do universities appear to be aware of the 
importance of CCM, but the topic is also being taught at more regional business schools. As an example, the Shandong University of Finance and Economics, where the author taught as part of a short-term university exchange, offers the undergraduate core course 'International Management- culture, strategy and behavior ' using the Chinese version of Luthan/Doh's textbook of the same name (2010).

\section{THE RESEARCH DESIGN OF THE STUDY}

Research objectives, methods and sampling will now be discussed. Subsequently, the results of the study will be presented.

\section{Research Question}

After a long period of economic isolation, many Chinese corporations still lack long-term experience in international economic activities. Recruitment of cross-cultural managers has focused more on language skills, rather than the differences in approaches and values in a different culture. Only a few courses on culture convey cultural differences and their implications for managers (Dong \& Liu, 2010). Therefore, it is questionable if Chinese business students, as possible future managers, are (already) aware of cultural differences, and if business schools are able to rely upon basic attitudes towards CCM when conveying its competencies. To see if this is the case, it was decided to conduct a survey on cultural awareness and cognitive cultural intelligence among Chinese undergraduate business students.

\section{Methods}

For the purposes of this study, a questionnaire was used as the research instrument (self-report survey). The questionnaire was designed in such a way as to measure all relevant variables. Ang et al. (2011) developed a Cultural Intelligence Scale (CQS) questionnaire which is comprised of 20 items (dealing with metacognitive, cognitive, motivational, and behavioural facets of CQ) and uses a 7-point Likert-scale. The author chose to focus on cognitive CQ only, using a 5-point Likert scale for all questions $(1=$ completely true; 5 = completely false). The questionnaire was then complemented by questions on cultural awareness (Cramer, 2007) with the same scale. The questionnaire was translated back and forth into/from the Chinese version, by language experts, to ensure equivalence.

\section{Data Collection (and Sampling)}

The study was conducted in a single location, a large university in China (Shandong University of Finance and Economics, Jinan), and is based on a culturally homogenous sample comprised of Chinese students with almost no level of international experience. The course focused on preparing undergraduate students enrolled in a business administration program to cope with challenges that can occur in international management. Two hundred and ten questionnaires were distributed to the participants in spring 2016. Two hundred and one (95.7\%) participants returned this survey. After checking the completed questionnaires, one hundred and ninety five (92.9\%) were determined to be valid.

Approximately 33\% of participants were male, with an average age of 21.3 (SD: 0.78 ). The vast majority $(95.9 \%)$ were in their third year of study and had never been to a foreign country, even in their free time, nor had they any foreign experience in study/job (93.9\%).

\section{Results}

A commonly-accepted rule of thumb is that an alpha of 0.6-0.7 indicates acceptable reliability. The criteria generally agreed upon for scale reliability is its cut-off value 0.7 (Peterson, 1994). Moreover, Moss et al. (1998) supported the view that Cronbach's alpha value of above 0.6 is generally acceptable. Concerning cognitive $\mathrm{CQ}$ the reliability results for the sample demonstrated very satisfactory reliability scores (0.81). However, the reliability of the seven items with regard to cultural awareness was unsatisfactory. Therefore, a factor analysis (principal component analysis) was done, and one item needed to be withdrawn. Following this re-calculation, the variable cultural awareness can be said to demonstrate an acceptable level of reliability (0.65). The overall reliability for the sample dealing with both questions referring to cognitive CQ and cultural awareness showed very satisfactory scores too (0.82).

Means $(1=$ completely true; 5 = completely false) and standard deviations concerning questions to cognitive CQ and cultural awareness are shown in Table 2. 
Table 2. Means and standard deviations of all items $(\mathrm{n}=195)$

\begin{tabular}{|l|c|c|}
\hline Item & Mean & Std dev \\
\hline $\begin{array}{l}\text { 1. Knowledge of own cultural background } \\
\text { and its influence }\end{array}$ & 2.09 & 0.69 \\
\hline $\begin{array}{l}\text { 2. Knowledge of legal and economic systems } \\
\text { of other cultures }\end{array}$ & 3.34 & 0.82 \\
\hline $\begin{array}{l}\text { 3. Knowledge of norms/life situations of } \\
\text { culturally different people }\end{array}$ & 2.59 & 0.81 \\
\hline \begin{tabular}{l} 
4. Knowledge of rules of other languages \\
\hline $\begin{array}{l}\text { 5. Knowledge of cultural values and religious } \\
\text { beliefs of other cultures }\end{array}$
\end{tabular} & 2.86 & 0.81 \\
\hline $\begin{array}{l}\text { 6. Knowledge of the marriage system of other } \\
\text { cultures }\end{array}$ & 3.32 & 0.80 \\
\hline $\begin{array}{l}\text { 7. Importance of empathizing with other } \\
\text { people }\end{array}$ & 1.30 & 0.50 \\
\hline 8. Learning foreign languages & 1.43 & 0.63 \\
\hline $\begin{array}{l}\text { 9. Knowledge of arts and crafts of other } \\
\text { cultures }\end{array}$ & 2.79 & 0.80 \\
\hline $\begin{array}{l}\text { 10. Knowledge of rules for nonverbal } \\
\text { communication }\end{array}$ & 3.02 & 0.84 \\
\hline $\begin{array}{l}\text { 11. Openness to strangers } \\
\text { 12. Dealing with cultural differences } \\
\text { interesting }\end{array}$ & 1.55 & 0.64 \\
\hline Cognitive CQ & 1.75 & 0.65 \\
\hline Cultural awareness & 0.82 \\
\hline
\end{tabular}

Note. Std dev = standard deviation

The respondents indicate that they strongly empathize with other people and would definitely learn the language of a potential host country. According to their statements, they are open to strangers and find it interesting to deal with the cultural differences of people. They are aware of their own cultural background and its influence. It is partly true that they know about norms and life situations of people different to them and that they know the arts and crafts of other cultures. As to knowledge of the rules of other languages, and nonverbal behaviors in other cultures, respondents also indicate a partial truth. They showed medium knowledge of cultural values and religious beliefs of other cultures. Familiarity with the marriage system, as well as the legal and economic systems of other cultures, are least developed according to the responses.
The sample indicates a medium score concerning cognitive CQ (3.06, SD: 0.82; items: 2,4-6,9-10). The best results deal with the knowledge of arts and crafts of other cultures and the knowledge of rules of other languages. The score regarding cultural awareness is quite low (1.75, SD: 0.65; items: 1,3,7-8,11-12) which indicates a moderately high level of being aware of cultural differences. The values relate to the importance of empathizing with other people, openness to strangers, and finding it interesting to deal with cultural differences.

Table 3 shows correlations between the items. The magnitude of correlations indicates that there is no linear relation between certain pairs of items, e.g. item 2 and item 11. However, for other pairs of items, respondents display correlated preference for their answers, where the correlation ranges from low to moderate. 
Table 3. Correlations ( $\mathrm{n}=195)$.

\begin{tabular}{|c|c|c|c|c|c|c|c|c|c|c|c|c|}
\hline $\begin{array}{c}\text { Correlation } \\
\text { s }\end{array}$ & $\begin{array}{c}\text { Item } \\
\mathbf{1}\end{array}$ & $\begin{array}{c}\text { Item } \\
\mathbf{2}\end{array}$ & $\begin{array}{c}\text { Item } \\
\mathbf{3}\end{array}$ & $\begin{array}{c}\text { Item } \\
\mathbf{4}\end{array}$ & $\begin{array}{c}\text { Item } \\
\mathbf{5}\end{array}$ & $\begin{array}{c}\text { Item } \\
6\end{array}$ & $\begin{array}{c}\text { Item } \\
\mathbf{7}\end{array}$ & $\begin{array}{c}\text { Item } \\
\mathbf{8}\end{array}$ & $\begin{array}{c}\text { Item } \\
9\end{array}$ & $\begin{array}{c}\text { Item } \\
10\end{array}$ & $\begin{array}{c}\text { Item } \\
11\end{array}$ & $\begin{array}{c}\text { Item } \\
12\end{array}$ \\
\hline Item 1 & 1.00 & & & & & & & & & & & \\
\hline Item 2 & 0.40 & 1.00 & & & & & & & & & & \\
\hline Item 3 & 0.27 & 0.44 & 1.00 & & & & & & & & & \\
\hline Item 4 & 0.27 & 0.29 & 0.34 & 1.00 & & & & & & & & \\
\hline Item 5 & 0.33 & 0.48 & 0.52 & 0.40 & 1.00 & & & & & & & \\
\hline Item 6 & 0.15 & 0.44 & 0.35 & 0.28 & 0.61 & 1.00 & & & & & & \\
\hline Item 7 & 0.19 & 0.06 & 0.12 & 0.07 & 0.20 & 0.14 & 1.00 & & & & & \\
\hline Item 8 & 0.29 & 0.13 & 0.17 & 0.16 & 0.13 & 0.09 & 0.32 & 1.00 & & & & \\
\hline Item 9 & 0.26 & 0.38 & 0.40 & 0.29 & 0.53 & 0.49 & 0.14 & 0.08 & 1.00 & & & \\
\hline Item 10 & 0.19 & 0.38 & 0.48 & 0.31 & 0.44 & 0.51 & 0.10 & 0.13 & 0.44 & 1.00 & & \\
\hline Item 11 & 0.19 & 0.03 & 0.22 & 0.06 & 0.09 & 0.08 & 0.23 & 0.22 & 0.21 & 0.16 & 1.00 & \\
\hline Item 12 & 0.15 & 0.20 & 0.21 & 0.14 & 0.15 & 0.17 & 0.25 & 0.30 & 0.18 & 0.22 & 0.49 & 1.00 \\
\hline
\end{tabular}

Note. ${ }^{*}$ Critical value for Pearson correlation for 200 samples at significance level of $\alpha=0.05$ is 0.117 , and thus, the correlation coefficient below this value should not be used

\section{Discussion and limitations}

The results of the survey indicate a medium value of cognitive CQ among Chinese undergraduate business students. According to Ang et al. (2011), the cognitive factor of CQ is a critical component of cultural intelligence because those with high cognitive CQ are less disoriented when interacting with people from different cultures. Learning foreign languages, in particular English, is quite widespread among Chinese business students and according to Cramer (2007), language skills have a positive impact on satisfaction and future prospects for multinational teamwork.

In part, China is generally more aware of cross-cultural variations than some Western countries. According to Jungbluth (2015) awareness of intercultural differences in China itself, for example between different regions, can be identified. According to the results of the study, Chinese business students are moderately well aware of cultural differences. Their empathizing with other people, openness to strangers, and interest in dealing with cultural differences are other good prerequisites for successful cross-cultural cooperation.

Although the research objectives have been achieved, the limitations to mention are related to the design of the study. First, cognitive CQ and cultural awareness were measured by the use of a self-report survey at a large university in China, with its usual disadvantages, such as inaccurate or invalid (jokesters) responses (Fan et al., 2006) and social desirability bias (Edwards, 1953). Respondents may have unrealistically estimated their cognitive CQ and cultural awareness. Nevertheless, some reassurance for the adequacy of the Cultural Intelligence Scale, which items about cognitive CQ were made use of, can be drawn from the results of the precise multiple reliability testing, and from the findings that proved its good predictive validity (Ang et al., 2007). The items dealing with cultural awareness had also undergone a reliability test (Cramer, 2007). Another limitation deals with the generalization of the collected data. There is enormous cultural 
heterogeneity within China that makes it difficult to generalize on a very large number of Chinese undergraduate business students, solely relying on one single survey at one university. Future research should extend the sample of business schools in China. However, the present study can contribute to the discussion about CCM in China, by providing insights into some aspects of the cross-cultural competencies of Chinese business students.

\section{CONCLUSIONS AND IMPLICATIONS}

The overarching goal of this paper is to identify cultural awareness and cognitive cultural intelligence among Chinese undergraduate business students.

In China, a rising interest in cross-cultural issues arose during the 1980s, which intensified over time. The growing number of Sino-foreign joint ventures and business cooperation in China itself contributed significantly to this. The rapidly increasing international expansion of Chinese companies supports the need to deal with cross-cultural differences.

The study shows that Chinese undergraduate business students are indeed moderately culturally aware and show medium cognitive CQ scores. A high degree of cultural awareness, as well as cultural intelligence, is a good prerequisite for today's global work environment.

\section{REFERENCE}

AACSB International (2016a). Eligibility procedures and accreditation standards for business accreditation. Retrieved from: http://www.aacsb.edu//media/aacsb/docs/accreditation/standards/ businessstds_2013_update3oct_final.ashx?la=en (Accessed 12 January 2017)

AACSB International (2016b). AACSB-accredited universities and schools in China. Retrieved from: http://www.aacsb.edu/accreditation/accredi ted-members/global-listing (Accessed 16 January 2017)

Ang, S., Van Dyne, L., \& Tan, M.L. (2011). Cultural intelligence. In R. J. Sternberg \& S. B. Kaufman (Eds.), Cambridge Handbook on Intelligence (pp. 582-602). New York: Cambridge Press.
https://doi.org/10.1017/CBO9780511977244

Ang, S., \& Van Dyne, L., (2008).

Conceptualization of cultural intelligence: Definition, distinctiveness, and nomological network. In S. Ang, \& L. Van Dyne, (Eds.) Handbook of cultural intelligence: Theory, measurement and applications (pp. 3-15). New York: Sharpe.

Ang, S., Van Dyne, L., Koh, C.K.S., Ng, K.Y., Templer, K.J., Tay, C., \& Chandrasekar, N.A. (2007). Cultural intelligence: Its measurement and effects on cultural judgment and decision making, cultural adaptation, and task performance. Management and Organization Review, 3, 335-371. https://doi.org/10.1111/j.17408784.2007.00082.x

Barsauskas, P., \& Schafir, S. (2003). Internationales Management. München; Wien: Oldenbourg

Cramer, T. (2007). Interkulturelle Zusammenarbeit in multinationalen Teams. Grin Verlag: München.

Dong, K., \& Liu, Y. (2010). Cross-cultural management in China. Cross Cultural Management: An International Journal, 17(3), 223-243. https://doi.org/10.1108/1352760101106833 3

Earley, P.C., \& Ang, S. (2003). Cultural intelligence: Individual interactions across cultures. Palo Alto, CA: Stanford University Press.

Edwards, A. (1953). The relationship between the judged desirability of a trait and the probability that the trait will be endorsed. Journal of Applied Psychology, 37, 90-93. http://dx.doi.org/10.1037/h0058073

Fan, X., Miller, B.C., Park, K.-E., Winward, B.W., Christensen, M., Grotevant, H.D., \& Tai, R.H. (2006). An exploratory study about inaccuracy and invalidity in adolescent selfreport surveys. Field Methods, 18(3), 223244. https://doi.org/10.1177/152822X06289161

Fuchs, M. \& G. Apfelthaler (2002). Management internationaler Geschäftstätigkeit. Wien, Berlin, New York: Springer.

Hemerling, J., Michael, D.C., \& Michaelis, H. (2006). China's global challengers - the strategic implications of Chinese outbound $M \& A$. BCG Report, Boston, MA: BostonConsulting Group. 
Hofstede, G. (1991). Cultures and organizations: Software of the mind. London: McGraw-Hill.

Hofstede, G. (2001). Culture's consequences: Comparing values, behaviours, institutions, and organizations across nations. 2nd edition, London: Sage.

Inkpen, A. C., \& Currall, S. C. (1998). The nature, antecedents, and consequences of joint venture trust. Journal of International Management, 4(1), 1-20. https://doi.org/10.1016/S10754253(98)00004-0

Jungbluth, C. (2008). Going Global, Crossing Cultures - Intercultural Management in Chinese Enterprises. International Journal of Chinese Culture and Management (IJCCM), 1(3), 274-288. https://doi.org/10.1504/IJCCM.2008.019590

Jungbluth, C. (2015). Going Global: Die internationale Expansion chinesischer Unternehmen. Baden-Baden: Nomos

Koyama, T. (1992). Japan: A handbook on intercultural communication. Sydney: National Centre for English Language Teaching and Research, Macquarie University.

Leung, K.; Bhagat, R.S., Buchan, N.R., Erez, M., \& Gibson, C.B. (2005). Culture and international business: Recent

advances and their implications for future research. Journal of International Business Studies, 36, 357-378. https://doi:10.1057/palgrave.jibs.8400150

Luthans, F., \& Doh, J.P. (2008/2010): International Management - Culture, Strategy and Behavior. 7th edition, New York: McGraw-Hill/Irwin, 2008 / China Machine Press, 2010.

Maugain, O. 2003. Managing multicultural R\&D Teams - an in-depth Case Study of a Research Project at CERN. Bamberg: DifoDruck.

Mergermarket Group (2016). Bumper year for Asia-Pac outbound M\&A. Retrieved from: http://www.mergermarket.com/pdf/AsPac_infographic.pdf (Accessed 11 January 2017)

Moss, S.C., Prosser, H., Costello, H., Simpson, N., Patel, P., Rowe, S., Turner S., \& Hatton, C. (1998). Reliability and validity of the PASADD - Checklist for detecting psychiatric disorders in adults with intellectual disability. Journal of Intellectual Disability Research, 42, 173-183. https://doi.org/10.1046/j.13652788.1998.00116.X

Oliver, C. (1997). Sustainable competitive advantage: Combining institutional and resource-based views. Strategic Management Journal, 18(9), 697 -713. https://doi.org/10.1002/(SICI)10970266(199710)18:9<697::AIDSMJ909>3.0.CO;2-C

People's Daily Online (2009). Chinese firms' outbound investment to face simplified procedures. 18 September 2009. Retrieved from:

http://english.peopledaily.com.cn/90001/90 778/90857/90861/6761782.html (Accessed 11 January 2017)

Peterson, R.A. (1994). A meta-analysis of Cronbach's coefficient alpha. Journal of Consumer Research, 21, 381-391. http://dx.doi.org/10.1086/209405

Ridley, C.R., Mendoza, D.W., Kanitz, B. E., Angermeier, L., \& Zenk, R. (1994). Cultural sensitivity in multicultural counseling: A perceptual schema model. Journal of Counseling Psychology, 41(2), Apr 1994, 125-136. http://dx.doi.org/10.1037/00220167.41.2.125

Schwartz, S.H. (1999). A theory of cultural values and some implications for work. Applied Psychology: An International Review, 48(1), pp.23-47. http://dx.doi.org/10.1111/j.14640597.1999.tb00047.x

Singelis, T.M. \& Pedersen, P. (1997). Conflict and mediation across cultures. In K. Cushner. \& R.W. Brislin (Eds.) Improving Intercultural Interactions: modules for cross-cultural training programs. Volume 2, Thousand Oaks, California: Sage.

Sternberg, R.H. \& Detterman, D.K. (1986). What is intelligence 


\section{ABOUT THE AUTHOR}

Tobias Cramer: tobias.cramer@vse.cz

Dr. Tobias Cramer was born in Leipzig, Germany. Dr. Cramer completed his studies of business and education at the University of Technology Dresden. Already during his studies, he gained broad practical experience in cross-cultural cooperation. Fascinated by cross-cultural similarities and differences, he addressed himself to crosscultural cooperation in multinational teams during his PhD study at the University of Economics in Prague. He is currently working as a lecturer and trainer in crosscultural management as well as crosscultural communication. His recent visiting lectures included the University of Northern Colorado/U.S. and the Shandong University of Finance and Economics/China. 